\title{
ELIAS LETWABA, THE APOSTOLIC FAITH MISSION, AND THE SPREAD OF BLACK PENTECOSTALISM IN SOUTH AFRICA
}

\section{Barry Morton}

Research Fellow, Department of History, University of South Africa mortonb@wabash.edu

\section{ABSTRACT}

This article argues that the little-known Elias Letwaba was the most influential African Pentecostal in southern African religious history. Using an array of primary sources, the article demonstrates the rapid growth of Pentecostal communities in the Northern Transvaal under Letwaba's control. Unlike other African Pentecostal ministers who inevitably abandoned the movement, Letwaba received significant support, funding, and publicity for his efforts. These factors, combined with his strong leadership role, contributed to his remaining within the white-led Apostolic Faith Mission and building up its African membership. As the founder of South Africa's first black-run seminary, the Patmos Bible School, Letwaba was able to propound and spread classic Pentecostal theology, although he placed a strong personal emphasis on holiness. He also placed a strong emphasis on faith healing as a means of attracting converts, and trained numerous evangelists to do likewise.

Keywords: Elias Letwaba; Apostolic Faith Mission; Pentecostalism; faith healing

\section{INTRODUCTION}

Although South Africa has had a large African Pentecostal constituency that dates back to the years following the Azusa Street Revival, very little is known about it. Concentrated in such groups as the Apostolic Faith Mission (AFM) and the Full Gospel Church, African Pentecostals found themselves relegated to second-class status by these white-run bodies soon after the initial fervour of conversions was completed. As a result of this marginalisation, segregated African Pentecostal congregations were given very little funding, publicity, or public support by their parent bodies.

\section{UNISA}


This situation was mirrored archivally as well - records were typically kept on white Pentecostal leaders and their congregations, while the African membership was usually undocumented. As a result, the best-known African Pentecostals are the modern faith-healing evangelist Richard Ngidi and the anti-apartheid activist Frank Chikane. ${ }^{1}$

Although virtually unknown, ${ }^{2}$ Elias Letwaba (1870-1958) was the most influential African Pentecostal preacher in South African history. Not only did he convert a significant percentage of the AFM's membership, but he was also responsible for keeping this large section of its membership within the church. While the early leaders of the AFM, John G Lake and P.L. le Roux, were able to bring large numbers of African converts and churches under their umbrella in the early years of the movement, they almost invariably lost them due to the racial leadership structure they created. ${ }^{3}$ Letwaba, on the other hand, was able to garner enough resources to maintain a cohesive organisation, and he resisted numerous opportunities to defect to other churches. Letwaba was further influential due to the fact that he established the Patmos Bible School, South Africa's first black-run seminary, where he trained a generation of evangelists. As a result of these strong influences, Letwaba perpetuated a form of evangelism derived from his friend and mentor, John G Lake, that emphasised "signs and miracles" in order to win conversions and retain members. This legacy was passed down to such legendary AFM preachers as Ngidi and Reinhard Bonnke in the modern era.

\section{EARLY LIFE AND CONVERSION TO THE AFM}

Letwaba's life is unusually well-documented for an African of his era, and was the subject of a (thin) biography by the Full Gospel Church missionary William Burton. ${ }^{4}$ Letwaba's family were Transvaal Ndebele, Berlin Mission converts who refused to let their son attend initiation ceremonies. Letwaba seems to have been more religious than either of his parents, attended a mission school, and was fluent in a number

1 A. Anderson, Bazalwane: African Pentecostals in South Africa (Pretoria: UNISA Press, 1992), 48-50; F. Chikane, No Life of My Own: An Autobiography (Eugene, OR: Wipf \& Stock, 2010); A. Khathide, What a Giant of Faith: The Story of Richard Ngidi's Ministry of Miracles (Johannesburg: AcadSA, 2010); and M. Nel and I. Burger, A Fire Falls in Africa: A History of the Apostolic Faith Mission of South Africa (Vereenigeng: CUM, 2008).

2 See Anderson, Bazalwane, 36-40; and C.R. De Wet, "The Apostolic Faith Mission in Africa 19081980: A Case Study in Church Growth in a Segregated Society" (PhD Dissertation, University of Cape Town, 1989), 65-71; and Nel and Burger, Apostolic Faith Mission, 41-6.G. Lindsay, John G Lake: Apostle to Africa (Dallas: Christ For All Nations, 1972), has two short chapters in Letwaba, but I have found this to be an inaccurate source.

3 See W. Hollenweger, The Pentecostals: The Charismatic Movement in the Churches (Minneapolis: Augsburg Publishing House, 1971), 170-4.

4 W.F.P. Burton, When God Makes a Pastor (London: Victory Press, 1934). 
of languages. ${ }^{5} \mathrm{He}$ was clearly drawn towards the ministry at a young age, and was ordained as an evangelist by the Lutherans and then was sent to Lydenburg to preach among the Bapedi. ${ }^{6}$ Remaining with the Berlin Mission for only a couple of years, he soon joined the Bapedi National Church schism. ${ }^{7}$ His motivations in doing so are not particularly clear, since Letwaba later downplayed his 17 years of experiences with various "Ethiopian" bodies such as the Bapedi National Church after joining the AFM. Letwaba later unconvincingly maintained that he left the Lutherans because its ministers were living lives of insufficient holiness, leaving one to speculate that he saw greater opportunities for himself with the new breakaway church. ${ }^{8}$ During his years with the Bapedi church it is clear that Letwaba had several different congregations in the Transvaal, during which time he petitioned the government for various licences and exemptions. ${ }^{9}$

By 1907 Letwaba had moved away from the faltering Bapedi National Church, and had "belonged to a number of different unrecognised denominations"10 in the interim. He was clearly seeking a stable home for his ministerial labours, a search that led him to the Rand where he and his close friend John Morwane took a leading role in Samuel Brander's Ethiopian Catholic Church in Zion, an offshoot of the African Methodist Episcopal church. ${ }^{11}$ Letwaba's biography also downplays his membership in this Ethiopian organisation, which, like the Bapedi National Church, was a black-run organisation with standard Protestant teaching. Instead, he foregrounded his involvement with the remnants of John Alexander Dowie's Zionist church in Johannesburg. Records indicate that he could not have been a member for more than a month at most, but this involvement was for him seminal: "It was among these 'Zionists' that Letwaba first came into contact with real vital religion... They would have nothing to do with human forms and ceremonies, but went to God's precious Word as their standard of authority." 12

The arrival of John G Lake's Pentecostal mission group from America, which formed the AFM in May 1908, decisively changed the situation. The AFM quickly absorbed the vast majority of the former Dowie adherents, and Letwaba and Morwane defected from Brander and also became members of South Africa's first Pentecostal

5 Ibid, $20-1$.

6 "The Mission Field: Waterberg," Comforter no. 10, 3 (1930): 7; "From the Mission Fields: Potgietersrust," Comforter N.S. no. 1, 5 (1932): 18.

7 See K. Ruther, The Power Beyond: Mission Strategies, African Conversion and the Development of a Christian Culture in the Transvaal (Hamburg: LIT, 2001), 140-8.

8 Cf. ibid, and Burton, 22.

9 See National Archives of South Africa, Pretoria (hereafter NASA), SNA 186 NA 3007/03; SNA 50 NA1743/02; SNA 141 NA 1429/03.

10 NASA SNA 472 NA2441/10 Hook to Godley, 29 July 1910.

11 See NASA SNA 401/771 S. Brander to Native Commissioner, 13 March 1908, which is signed by Letwaba and Morwane, and also SAB GNLB 205 File 34 Ethiopian Catholic Church in Zion.

12 In the 1930s Letwaba referred to this group as the "Zion Apostolic Church": Burton, 22, 28, 51. 
Church. ${ }^{13}$ Letwaba was clearly swept up in the fervour of the arrival of the Pentecost in South Africa - a time when the introduction into the country of dramatic faith healings and speaking in tongues were followed by large-scale conversions. He clearly found Pentecostalism far more to his liking than orthodox Protestantism, which in his mind favoured "a mixture of God's commands and man's traditions". As a Pentecostal, Letwaba instinctively agreed with its doctrines barring infant baptism and confirmation: "you are a Christian, and all you have to do is be good, go to Church and take the sacrament." ${ }^{14}$ The AFM's emphasis on Spirit baptism and holiness, he believed, promoted a higher level of spirituality. He was also attracted to the leadership of John G Lake, whom he saw as a man of immense spiritual power. Closely linked to these two factors was the strong non-racial ethos of the early AFM, which held integrated services in Johannesburg. When Letwaba first joined the AFM, Lake welcomed him into the church and kissed him in front of a largely-white audience, calling him "my brother". ${ }^{15}$ According to Letwaba, this demonstration of "such love, such uncompromising conviction and speech from a white preacher were absolutely new to him, and it won his heart". ${ }^{16}$ Letwaba then went to Lake's house for long discussions about Pentecostalism, before finally moving in with him and living with him for some six months in Johannesburg. Within a short time he began speaking in tongues "at a native conference" and thus received his Spirit baptism. ${ }^{17}$

\section{THE ESTABLISHMENT OF THE AFM IN THE WATERBERG}

During 1909, Letwaba and the AFM made a concerted attempt to evangelise in the Waterberg and other parts of the Northern Transvaal. Although this initial attempt was in many ways a fiasco, nevertheless Letwaba was able to establish a church in his home area. Subsequent evangelical efforts, in 1911 and afterwards, would make the Waterberg and surrounding areas into an AFM stronghold that made up a significant portion of the church's membership.

Letwaba himself was the instigator of the AFM's work in the Northern Transvaal. In February 1909 he appeared before the AFM's executive, and asked for funding to evangelise in the Waterberg, "where he feels called to go and labour". ${ }^{18}$ After receiving the council's blessing and some funding, he went to the Waterberg with two evangelists. Within a few months he had built a church on some of his family's

\footnotetext{
13 Ibid, 21, 31.

14 Ibid, 22.

15 Ibid, 51.

16 Ibid, 52.

17 "The Raising of the Dead," The Apostolic Faith no. 11 (1909): 1.

18 Apostolic Faith Mission Archives, Johannesburg (hereafter AFM), "Minutes of the Apostolic Faith Mission Executive Committee, 1908-14," entry for 18 February 1909.
} 
land, and received some financial assistance from the AFM for construction costs. ${ }^{19}$ In the meantime, he continued to encourage the AFM to use the area as a springboard for efforts further north. This led Lake to organise a party of 17 AFM workers and to set out for Potgietersrust in June 1909.

Accounts of the 1909 AFM expedition vary dramatically. According to the Rand Daily Mail, the expedition was a disaster, with very few conversions made. Not only were few souls saved, but nearly half of the party died of malaria, including Lake's fiancée, Ada White, and several of his favourite young evangelists. ${ }^{20}$ Lake initially made few remarks about the trip, except to note the "awful conditions of disease among the natives in the Waterberg district," where two-thirds were said to suffer from syphilis. ${ }^{21}$ By the time of Lake's fund-raising trip to the United States later in the year, these deaths had been forgotten, while previously unheard-of miracles were publicised. Letwaba was held to have raised four people from the dead, with choirs of angels appearing at his services, along with numerous other miracles occurring. ${ }^{22}$ In later years, the stories grew even more outlandish, with the expedition having allegedly cured so many people that the Prime Minister Louis Botha sent dozens of ox wagons at government expense to assist. ${ }^{23}$

If these initial accounts that "hundreds were healed" and that "the ordinary business and social life [of Potgietersrust] were almost suspended" 24 while the multitudes were saved were exaggerated, it is nevertheless true that a number of conversions did take place. ${ }^{25}$ By the middle of 1910 Letwaba was able to report that he was holding many meetings in the area, "every day and night we held powerful meetings" and that many of his hundreds of new converts were speaking in tongues. ${ }^{26}$ Further AFM efforts in the region in 1911, usually assisted by Letwaba, led to significant growth in its membership. ${ }^{27}$ According to the ever-hyperbolic Lake, this effort "was in depth and power beyond that of anything that has taken place in the work in South Africa". ${ }^{28}$ During drought conditions later that year, Letwaba

19 Ibid, entry for 16 July, 1909.

20 “Choosing to Die," Rand Daily Mail 7 July 1909, p. 7.

21 "Letter from Bro. J.G. Lake," Confidence no. 2, 8 (1909): 185.

22 "God Has Visited Africa," The Apostolic Faith no. 11 (1909): 1.

23 Lindsay, 35-6. An official investigation into the AFM's claims showed that no resurrections had occurred and that most of the claims could not be substantiated, NASA TAB SNA 472 NA2441/10 Hook to Godley, 29 July 1910.

24 Burton, 70.

25 "Work Among the Natives in the Zoutpansberg and Elsewhere," Weekly Evangel (June 1916): 12.

26 "Pentecost Among Africans," Apostolic Faith no. 14 (1910): 3-4.

27 See R.H. van de Wall, "The Mission Field Zoutpansberg," Comforter no. 1, 8 (1911); "Brother J.O. Lehman's Letter," and H.M. Turney, "Visiting the Famine Sufferers in Africa," Bridegroom's Messenger no. 5, 115 (1912): 1.

"Native Work," Comforter 1, 8 (July-Aug 1911): n.p. 
apparently won even more converts by correctly prophesying that rain would fall the next day, and "hundreds were saved" yet again..$^{29}$

The upshot of these and other continuing efforts was that the AFM grew in the Waterberg and Pietersburg region. By 1919 Letwaba had 13 ministers working under him in the area ${ }^{30}$ and the membership would continue to expand rapidly through the 1920s. By this time he had "a strong Pentecostal work with a membership running into several thousands". ${ }^{31}$ Later records show him with even more:

He starts his services at 5:30 am and continues till 9 at night or even later, often speaking at length in five or six meetings a day, or lecturing for six hours in the Bible School. ${ }^{32}$

Although exact statistics are few and far between, it would appear that Letwaba's congregations in the Transvaal made up around a quarter of the AFM's black membership. ${ }^{33} \mathrm{He}$ was easily the most successful evangelist in the AFM.

Letwaba learned his evangelising techniques from John G Lake, who in turn was a protégé of the famed inventor of modern faith healing, John Alexander Dowie. Lake, who dominated the AFM in its early years, made it a specific policy of his church to use faith healing to win African converts. According to Lake, "the heathen has very little conception of the Christian God". Hence it was important to demonstrate "the character and power of God unto mankind, so that it appeared to the natural sense of the natural mind. Any man could understand a sick man being healed. He could see it! His senses comprehended it!"'34 In order to further this policy, Lake spent considerable time training two African faith healers in the AFM - Elias Letwaba and Edward Lion.

Letwaba was an extremely diligent and effective student of faith healing, and he used all the classic techniques. In order to build up the charisma necessary to orchestrate successful healings, ${ }^{35}$ he created a new autobiography that emphasised both a sacred childhood as well as a host of miracles that he claimed to have performed from his early life onwards. According to Letwaba, he first sensed a divine mission as a youth when he saved an old man from drowning in a raging river. According to these accounts he was laying hands on the sick and curing them as early as 1890

29 "What the Lord is Doing Among the Natives," Comforter no. 1, 9 (1912): 12; Burton, 77-81.

30 See "Verslag van Bro. Letwaba," and "Ministers in the Native Work," De Trooster (Mar 1919): 3, 6.

31 "Waterberg," Comforter no. 9, 10 (Oct 1929): 8.

32 Burton, 104.

33 In 1945 Letwaba had some 7700 members in the Waterberg, out of a total African membership of around 30000 .

34 John G Lake, "What God Hath Wrought," Comforter 1, 4 (Dec-Feb 1911): 7.

35 The techniques of faith healing are fully described in B. Morton, "John Alexander Dowie and the Invention of Modern Faith Healing, 1882-87," 11 June 2015, https://www. academia.edu/12444505/John_Alexander_Dowie_and_the_Invention_of_Modern_Faith_ Healing_1882-89 (accessed 16 July 2016). 
when he was with the Berlin Mission some 18 years prior to the Pentecost. ${ }^{36}$ After wrestling with sin and being unhappy in various Protestant congregations, he joined the AFM and began to raise the dead. Lake's version of this testimony is:

A girl who was raised from the dead was the daughter of a noted man in his tribe. He sent for a native preacher, a man in whose soul the mighty power of God had come to live. He came and knelt by the cot on which the dead girl lay, and went away again. At three o'clock in the morning the father of the girl went for him again, and found him on his face. He asked him to pray again. All that were in the hut got down on their knees. The very atmosphere of heaven filled the place. The brother put his hand on the girl's forehead and defied death in the name of Jesus, and commanded her spirit to return. Then the body moved, the eyes opened, and she arose and walked. ${ }^{37}$

Such testimonies featuring reworked autobiographies were used by Letwaba, as by other faith healers, at the beginning of healing services. ${ }^{38}$ Because a charismatic reputation is of prime importance in creating a sense of expectancy amongst those seeking healing, faith healers of Letwaba's era typically inserted anachronistic past healings into their testimonies. ${ }^{39}$ And like other faith healers of his era operating in rural areas, Letwaba had others preannounce his arrival, so that a spirit of tension and expectancy would arise before he got there: "The waiting ones were almost discouraged and thought I would not come anymore. Great was the rejoicing when they heard the singing of those who accompanied us and they came to meet us with songs of praises and prayer." ${ }^{40}$

Events bearing all the hallmarks of staged healings were commonly used, including many "fake cripple" events, in which ostensibly handicapped people "bedridden for 30 years" were instantly healed, able to walk again, while "the blind" had their vision restored. ${ }^{41}$ Such events were combined with numerous reports of "raising the dead" in order to create excitement in the local population. Government officials sent to verify some of his miracles were unable to do so, and Letwaba had to backdate some of his claims by 12 years in order to save face. ${ }^{42}$

The Northern Transvaal region seems to have been a fertile ground for faith healing. The local population had a traditional belief system that attributed most disease to supernatural factors rather than to natural causes, and as a result the area's European doctors found that an extremely high proportion of the patients who came to see them were suffering from psychosomatic symptoms. If the claims of these

\footnotetext{
36 Burton, 18-21.

37 "The Raising of the Dead," The Apostolic Faith no. 11 (1909): 1.

38 "From the Mission Fields: Potgietersrust," Comforter N.S. no. 1, 5 (1932): 18.

39 Morton 2015, 8-11.

40 "From the Mission Fields: Potgietersrust," 18.

41 E.g. "Potgietersrust," Comforter N.S. no. 1, 8 (1932): 22; TAB SNA 472 NA2441/10 Hook to Godley, 29 July 1910.

42 NASA TAB SNA 472 NA2441/10 Hook to Godley, 29 July 1910.
} 
veteran doctors in the region in the early 1960s are correct, some three quarters of all patients they saw were not suffering from organic diseases at all. ${ }^{43}$ As I have argued elsewhere, ${ }^{44}$ a trained charismatic healer who understood how to use the psychology of the placebo effect was therefore in a strong position to cure the sick and to effect conversions in their aftermath. Surveys of African Protestants in the Northern Transvaal at this time showed that 58 per cent had converted after being prayed for while ill, while "amongst the members of the Native Separatist or Pentecostal churches, this tendency is even more pronounced". ${ }^{45}$ For Letwaba, like Lake, the performance of miracles was of prime importance in evangelising, as it was through such events that God was "revealing himself powerfully in our midst". ${ }^{4}$

\section{LETWABA'S ROLE AS OVERSEER IN THE AFM}

Letwaba, although never nominally in charge, was the de facto leader of the AFM's African membership for almost 50 years. His close association with Lake, his success as an evangelist, his renown as a man of God, and his indefatigable work rate meant that he enjoyed tremendous respect throughout the church. As a result he was able to attend what were otherwise all-white meetings and conferences and could speak to these audiences with a degree of frankness. Letwaba's role, in fact, solved a serious problem for the AFM, which struggled to successfully incorporate African congregations into the organisation. Although the church propounded a nonracial ethos in its early years, even then the leadership was all white. So while the majority of the members and evangelists were African, ${ }^{47}$ they received very few subsidies from wealthier white congregations due to the church's segregationist policy. Letwaba's half-century long role in the AFM, then, was to exist as a kind of human resolution to these inherent contradictions.

The unequal, segregated structure of the AFM first emerged within two years of its founding, when Lake declared that all African evangelists needed to work under white supervision. African preachers could only be licensed by a white supervisor, while black congregations were placed under the control of the local white assemblies. ${ }^{48}$ While joint, if segregated, baptisms and services were allowed

43 Cullen Library, University of the Witwatersrand, Church of the Province of South Africa Historical Papers A3181 "Christian Beliefs in Sekhukhuniland," 9.

44 B. Morton, "Shembe and the Early Zionists: A Reappraisal," New Contrée no. 69 (2014): 83-6; idem 2015.

45 Cullen Library, University of the Witwatersrand, Church of the Province of South Africa Historical Papers A3181 "Christian Beliefs in Sekhukhuniland," 18.

46 "The Mission Field: Waterberg," Comforter no. 10, 3 (1930): 7.

47 Lake, "What God Hath Wrought," 7.

48 Ibid; AFM, "Minutes of the Apostolic Faith Mission Executive Committee, 1908-14," entry for 6 May, 1910; "Minutes of the Apostolic Faith Mission Executive Committee, 1915-1920," entry for 2 February, 1915. 
for about a decade, in 1917 the AFM forbade black members from attending white services. It then quickly became church policy to discourage "social equality between Whites and Natives". ${ }^{49}$ The AFM then, like the Pentecostal movement in America, came to reflect institutionalised racist values once the initial fervour of the Pentecost faded.

Beginning in 1910, African AFM members fell under the jurisdiction of a new "Native Council", consisting of three African overseers and three European members. During the next decade this council would evolve to include five overseers, and would be overseen by a white "Superintendent of Missions". ${ }^{50}$ Letwaba was the one constant presence on these leadership committees, and the AFM, quite simply, could never keep any of the other selected African leaders within the organisation due to its policies. As a result of his seniority and influence, he was often tasked with interceding between disgruntled African ministers.

Letwaba's longevity can be partly attributed to the fact that he received differential treatment. First, in the course of evangelising the Waterberg/Pietersburg area, he was given substantial support by the AFM. Not only were a score of white missionaries sent to assist him, but considerable funds and publicity also attended these efforts. Second, Letwaba was one of only two African ministers in the AFM to be paid a salary by the organisation. By the early 1920 s he was receiving $£ 12$ a month for his efforts, ${ }^{51}$ although it was the express policy of the AFM that no African preacher "associated with the Apostolic Faith Mission receives any salary". 52 Additionally, Letwaba was given complete control over his districts, and from the start did not have to receive permission from his supervisors to appoint evangelists. ${ }^{53}$ As a senior-ranking member, Letwaba could attend Executive Committee meetings if he was in town, and his letters, his activities, and his addresses were often printed in the church's publications. At times, he could speak frankly, for instance in 1919 telling the AFM Executive about his "hopes that the White brethren would now think of their poor Native brethren" in terms of funding issues. ${ }^{54} \mathrm{He}$ was able to chide white AFM members about their racist attitudes, reminding them "of the love, in the early days, between the white and the native brethren," 55 and admonishing them for

49 AFM "Minutes of the Apostolic Faith Mission Executive Committee, 1915-1920," entry for 17 June, 1917.

50 See De Wet, 93-6.

51 Burton, 91. Edward Lion, the Overseer of Basutoland, was also paid $£ 5$ a month until his expulsion in 1923.

52 Lake, "What God Hath Wrought," 7.

53 AFM, "Minutes of the Apostolic Faith Mission Executive Committee, 1908-14," entry for 25 June, 1909.

54 AFM, "Minutes of the Apostolic Faith Mission Executive Committee, 1915-1920," entry for 7 January, 1919.

55 "Potgietersrust," Comforter no. 11, 2 (1931): 6. 
seeing him as nothing but a "black worm" even when he healed them. ${ }^{56}$ So despite repeated attempts by other Pentecostal, Ethiopian, and Zionist churches to lure him away from the AFM, Letwaba remained within the organisation. ${ }^{57}$

The contrast between Letwaba and other African overseers is striking. Almost none of them, with the exception of the Basotholand overseer Edward Lion, were provided with money. Andrew Oliphant, for instance, was appointed as one of the first overseers and was in charge of both the Orange Free State and Eastern Transvaal African congregations through the church's first decade. As Oliphant later noted, "during all this time I received no pay, I lived upon the voluntary donations of the members of the church".$^{58}$ Initially, Oliphant was given considerable leeway by John G Lake, who sent him to evangelise in Natal and other areas and who rubberstamped his choices for local evangelists..$^{59}$ Once Lake left, Oliphant began to chafe under subsequent supervisors, and was eventually admonished by the Executive Committee in 1915 "for indiscriminate ordaining of ministers and doing it privately instead of at open conference". ${ }^{60}$ As a result of these factors, Oliphant left the AFM and took some 4200 members with him when he formed the Apostolic Faith Assembly of South Africa. Instead of trying to address the situation constructively, the AFM leadership ascribed Oliphant's departure (as it always did in these cases) as being due to his "unwillingness to submit to discipline". ${ }^{61}$

A similar case in point was Elias Mahlangu, who was appointed an overseer by P.L. le Roux. Mahlangu, a longstanding and loyal associate of Le Roux's, was preaching out of his own house in the Boksburg location. His many followers referred to it as a "shanty church", a place where the famed prophet Engenas Lekganyane was converted. ${ }^{62}$ Mahlangu referred to his section of the AFM as the "Zion Apostolic Church" (ZAC), which, as we saw earlier, Letwaba had joined prior to the formation of the AFM. Le Roux had led the ZAC into the AFM, but many of its members preferred to retain the name due to its referencing of the sacred term "Zion". Le Roux himself was not at odds with this, and when African congregations joined the AFM he gave them the option of referring to themselves as either AFM or ZAC members. ${ }^{63}$

56 Cited in De Wet, 70.

57 These attempts began early in 1910 and continued throughout his career, AFM, "Minutes of the Apostolic Faith Mission Executive Committee, 1908-14," entry for 11 November, 1910; Burton, 84-5, 101-2.

58 NASA SAB GNLB 205 File 22 "The Apostolic Faith Assembly of South Africa."

59 AFM, "Minutes of the Apostolic Faith Mission Executive Committee, 1915-1920," entry for 2 February, 1915.

60 Ibid.

61 NASA SAB GNLB 205 File 22 "The Apostolic Faith Assembly of South Africa."

62 See "Zion in South Africa," Leaves of Healing no. 35, 25 (1915): 392; E.K. Lukhaimane, "The Zion Christian Church of Ignatius (Engenas) Lekganyane, 1924 to 1948: An African Experiment with Christianity" (MA Dissertation, University of the North, 1980), 16.

63 AFM, "Minutes of the Apostolic Faith Mission Executive Committee, 1915-1920," entries for 20 February 1915 and 25 August, 1915. 
Mahlangu, however, was not paid and was placed under the supervision of Letwaba. Matters came to a head in 1916, when Mahlangu sought increased autonomy within the church. Again, matters such as certificates were important, since the AFM would not give certificates to ZAC preachers such as Engenas Lekganyane. ${ }^{64}$ Although Mahlangu expressed a willingness "to cooperate on the understanding that they would be permitted to carry on their work independently," he also left the AFM with thousands of members when this request was refused..$^{65}$

During the 1910s and 1920s the founders of most of South Africa's major independent churches were AFM members who, like Oliphant and Mahlangu, went out on their own - Edward Lion, Paul Mabiletsa, Engenas Lekganyane, Christina $\mathrm{Nku}$, and Isaiah Shembe. One has to conclude that had the AFM supported more of its talented African evangelists in the way it did Letwaba, there would be far more Pentecostals in South Africa and far fewer Zionists.

An additional feature of Letwaba's role as overseer was his promotion of a strong role for women within his region. Although he only accepted male students in his Bible School, ${ }^{66}$ he appointed the AFM's first African female evangelists, although data is too sketchy to see how this situation evolved over the decades. Due to his overwhelmingly busy schedule that involved ministry, education, and supervision, Letwaba made strong use of female members to assist him in getting all aspects of his work completed. This assistance ranged from school teaching, arranging trips, evangelising, and laying hands on the sick. ${ }^{67}$ In addition to holding annual conferences for the women of his district, Letwaba repeatedly highlighted the contributions of these "sisters" in his letters and reports - far more so than most AFM leaders of his era.

\section{THE PATMOS BIBLE SCHOOL}

In $1924{ }^{68}$ Letwaba conceived, built, and began South Africa's first black-run seminary adjacent to the grounds of his main congregation in the Potgietersrust location. Although he had the blessing of the AFM to undertake this task, he was not given financial support at all. Instead, the AFM sought to raise funds for a whites-only seminary, which it only succeeded in starting five years later! Letwaba would go on

64 Lukhaimane, 17.

65 See AFM "Minutes of the Apostolic Faith Mission Executive Committee, 1915-1920," entries for 13 December 1915 and 12 May 1916; SAB GNLB 205 File 61 "Zion Apostolic Church."

66 "Missionary News: Potgietersrust," Comforter N.S. no. 2, 4 (1933): 8.

67 E.g. see "Missionary News: Potgietersrust," Comforter N.S. no. 2, 12 (1933): 9.

68 There are occasional references to1930 as the opening date, but it opened in 1924. See "The Mission Field," Comforter 4, 4 (July-Aug 1924): 4; M. Nel, “A Hundred Years of Theological Training in the Apostolic Faith Mission of South Africa," Acta Theologica no. 34, 1 (2014): $112-3$. 
to run Patmos as an unaffiliated and unlicensed seminary for over a decade, training a large number of evangelists from across southern Africa.

By the early 1920s Letwaba had a strong base in the Waterberg area. He was the minister of some six different AFM congregations (with over 1400 members) at his home base near Potgietersrust, most of which he preached to every Sunday by himself. ${ }^{69}$ Letwaba was also in a strong financial situation, and could combine his AFM salary with offerings from his congregations. Letwaba's financial situation was also improved by his second marriage to one of his members, Louisa, who had inherited a large piece of farmland. ${ }^{70}$ It was this farm that basically enabled Letwaba to launch Patmos, since produce from it could be used either to feed or to support the students.

Letwaba seems to have conceived the Patmos Bible School as a venue for counteracting the spread of Zionism, which he attributed to poor knowledge of the Bible among African converts and preachers. His engagement with the Zionist schisms of Elias Mahlangu and Edward Lion, both of whom seceded from the AFM after having been under his supervision, led him to the following conclusion:

Again and again Letwaba saw that the young churches must have scriptural, sane teaching, if they were to be saved from error. The most fanatical absurdities were liable to occur if the leaders did not know their Bibles. Indeed from time to time wild prophecies had been given... Such errors showed Letwaba and the saints under his ministry how much a Bible school was needed. ${ }^{71}$

The importance of this self-referenced contrast between Letwaba and the Zionist movement can hardly be understated. Letwaba, by the early 1920s, had at his disposal all the necessary means to establish his own independent church - as many of his former colleagues in the AFM had already done. Edward Lion himself obtained land first in Basutoland in 1920 and later in the Transvaal to build his own "Zion" there. His example was later followed in 1938 by Engenas Lekganyane and the Zion Christian Church. Elias Mahlangu would undoubtedly have done the same thing had the ZAC's resources permitted it. All these individuals and their ideas were wellknown to Letwaba.

The actual Patmos building cost Letwaba about $£ 40$ to make. He made the bricks himself on his farm, and also made considerable use of donated building materials from both white and black AFM members. ${ }^{72}$ This building came to include dormitories for the students to live in, while a school for local AFM children was also added to it. Letwaba developed a three-year course for his students, which not only included Bible studies but also other classic subjects and oratory. In order to cater

69 "Conference of Native Ministers," Comforter N.S. no. 2, 2 (1932): 11.

70 Burton, 97; NASA SAB MHG 4053/59 "Elias Mpahlele Letwaba".

71 Ibid, 91.

72 Ibid, 93; “The Mission Field," Comforter 4, 4 (July-Aug 1924): 4. 
to his students' needs, classes were conducted in Sepedi. Through the 1930s Patmos had about a dozen students at any one time, and graduated them on a regular basis. ${ }^{73}$ His primary school, meanwhile, was licensed and had several hundred students.

Although we lack specific details about the curriculum, there can be little doubt based on his printed sermons and letters that Letwaba taught his students classic Pentecostal theology. He viewed mankind as living in the period of the Latter Rain, with Jesus' return to earth being imminent. He emphasised on many occasions the importance of baptism in the Holy Ghost. "The Holy Spirit should be manifested in our lives, not only in speaking in other tongues, but also in works and deeds...If people have the Holy Spirit, they should prove it in their lives. It grieves the Spirit when people say they have the baptism from on high and their lives do not bear witness to it." "74

Letwaba was insistent on the necessity of living a life free from sin in a state of holiness. In his mind, this was the key difference between the Pentecostals and mainline Protestant denominations - which were highly deficient in this regard. "Pray for me, and for the work of God. I desire to see that God's people live holy lives, for he himself said, 'Be ye holy, for I am holy'." ${ }^{75}$ As an overseer and trainer of ministers, Letwaba repeatedly exhorted to his underlings to "show your people how to live in holiness of life by living that life yourself'. ${ }^{76}$

Like many AFM members of his era, he was against the use of modern medicines and viewed sickness and disease as having Satanic origins. For Letwaba, living a Christian life thus meant engaging in a constant battle with Satan - whether to preserve one's faith or to preserve one's health. To be sick was "to be afflicted by the powers of darkness" or "to be attacked by the enemy". "Writing about one of his students who engaged in such struggles, he stated:

Last week, David Semola had a very severe attack from the enemy, and a certain Amossi said in a mocking voice, 'So there he lies! And you can indeed let such people rise!' We praise the Lord, for when two of the students had prayed for him he did indeed rise, and is back in school, attending the classes. ${ }^{78}$

On an overall basis, there is not a lot to distinguish his preaching from that of other AFM ministers of his era. ${ }^{79}$ We can surmise that the preaching of the AFM founders John G Lake and Tom Hezmalhalch, which Letwaba heard in Johannesburg in 1908-

73 "Missionary News: Potgietersrust," Comforter N.S. no. 2, 12 (1933): 8.

74 "Potgietersrust," Comforter no. 11, 2 (1931): 6.

75 "Encouraging News: Potgietersrust," Comforter N.S. no. 3, 4 (1934): 13.

76 Burton, 115.

77 "The Mission Field: Waterberg," Comforter no. 10,3 (1930): 7; “The Mission Field: Potgietersrust," Comforter no. 10, 8 (1930): 5.

78 "The Mission Field: Waterberg," 7.

79 Some reprinted sermons of his are in Burton, 108-15; and "Potgietersrust," Comforter no. 11, 2 (1931): 6 . 
9, made a lasting impression on him. As a result, the AFM endorsed his teachings and sent senior members to attend Patmos graduation ceremonies.

In addition to these studies, Letwaba also taught his students the forms of dramatic faith healings that he had learned himself from Lake in Johannesburg. Such training was done in the field and was performed before live audiences:

Yesterday a poor woman was brought here who was wrapped up with plasters, and who was so sick, that she could not eat or sleep, as there was a terrible tumour in her throat. I called for three of the Bible students, and together we prayed for her with the laying on of hands in the name of our Lord Jesus. She was then taken away home, and this morning, very early, to my surprise came to visit me as she had received a complete healing. ${ }^{80}$

In addition to being taught by Letwaba, Patmos students also met such internationally-known faith healers as Cyrus Fockler, who visited the school in $1927 .{ }^{81}$

Following their graduation from Patmos, his students went out and made faith healing their primary vehicle of spreading the gospel:

Brother Lukas Mantso, a former student of Patmos Bible School is laboring at Blaauwberg and he tells us the Lord wonderfully blessed the sisters in that area. The heathens gladly accept the gospel message, marvelous healings occurred and many were saved through the healing of the sick. Devils were also cast out as in the days of Christ on earth.

Brother Nathaniel Mokone from Thabina related of a child that was declared to be dead, but in answer to prayer God restored the child to its parents alive and healed. He also reports the healing of a woman who was given up as incurable, and many other mighty deeds are done by the almighty arm of God. The heathen are gathered in, holiness is increasing in their lives. ${ }^{82}$

Patmos seems to have closed down in 1935, after a mere 11 years, although it may have continued in existence for longer. As Letwaba aged, he seems to have cut back on many of his activities, and he made far fewer reports about his activities after 1935. The AFM later opened other programmes for training its African evangelists in order to make up the deficit. ${ }^{83}$

\section{CONCLUSION}

Elias Letwaba died in late $1958,{ }^{84}$ a respected leader inside and outside the church. Although childless, he left behind a considerable estate that indicates he was a wealthy

80 "The Mission Field: Waterberg," 7.

81 "Brother Fockler's Visits," Comforter 7, 6 (June 1927): 9. Fockler had worked as a faith healer for John Alexander Dowie, and then later for Maria Woodworth-Etter.

82 "From the Mission Fields: Potgietersrust," Comforter N.S. 1, 4 (Aug 1932): 12.

83 Nel, 115-6.

84 His obituary, composed by C.J. Jacobs, is in Comforter, (June 1959): 21. 
man by the standards of the day. ${ }^{85}$ He clearly played a central role in the spread of Pentecostalism among Africans in the Transvaal, as well as in making a concerted effort to maintain the integrity of the Pentecostal message in the face of schisms and syncretism. His story gives credence to the proposition that if white-run churches of his era had afforded their African ministers and leaders sufficient support, leadership opportunities, and status, they would have been far more successful. Letwaba's legacy, though, is somewhat clouded by his perpetuation of faith healing as a means of evangelisation. Using dubious techniques learned from John G Lake, Letwaba trained a new generation of faith healers in the AFM. By the 1960s AFM preachers such as Richard Ngidi and Reinhard Bonnke adopted these methods and went on to use them in mass campaigns across southern Africa and beyond.

\section{REFERENCES}

Anderson, A. Bazalwane: African Pentecostals in South Africa. Pretoria: UNISA Press, 1992. Burton, W.F.P. When God Makes a Pastor. London: Victory Press, 1934.

Chikane, F. No Life of My Own: An Autobiography. Eugene, OR: Wipf \& Stock, 2010.

De Wet, C.R. "The Apostolic Faith Mission in Africa 1908-1980: A Case Study in Church Growth in a Segregated Society." PhD Dissertation, University of Cape Town, 1989.

Hollenweger, W. The Pentecostals: The Charismatic Movement in the Churches. Minneapolis: Augsburg Fortress, 1972.

Jacobs, C.J. "Verslag Aangaande Oorlye en Begrafnis van E.M. Letwaba." Comforter no. 26 (1959): 21.

Khatide, A. What a Giant of Faith: The Story of Richard Ngidi's Ministry of Miracles. Johannesburg: AcadSA, 2010.

Lake, J.G. "Letter from Bro. J. G. Lake.” Confidence no. 2, 8 (1909): 185.

Lake, J.G. "What God Hath Wrought." Comforter no. 1, 4 (Dec-Feb 1911): 7-8.

Lindsay, G. John G Lake: Apostle to Africa. Dallas: Christ for All Nations, 1972.

Lukhaimane, E.K. "The Zion Christian Church of Ignatius (Engenas) Lekganyane, 1924 to 1948: An African Experiment with Christianity.” MA Thesis, University of the North, 1980.

Morton, B. "Shembe and the Early Zionists: A Reappraisal." New Contrée no. 69 (2014): 71-92.

Morton, B. "John Alexander Dowie and the Invention of Modern Faith Healing, 1882-87," 11 June 2015, https://www.academia.edu/12444505/John_Alexander_Dowie_and_the_Invention_ of_Modern_Faith_Healing_1882-89 (16 July 2016).

Nel, M. "A Hundred Years of Theological Training in the Apostolic Faith Mission of South Africa," Acta Theologica no. 34, 1 (2014): 108-26.

85 NASA SAB MHG 4053/59 "Elias Mpahlele Letwaba" shows that he had over $£ 750$ in cash plus two pieces of private property in assets. He employed the same law firm as the Lekganyane ZCC dynasty. 
Nel, M., and I. Burger. A Fire Falls in Africa: A History of the Apostolic Faith Mission of South Africa. Vereenigeng: CUM, 2008.

Ruther, K. The Power Beyond: Mission Strategies, African Conversion and the Development of a Christian Culture in the Transvaal. Hamburg: LIT, 2001.

Turney, H.M. "Visiting the Famine Sufferers in Africa." Bridegroom's Messenger no. 5, 115 (1912): 1 .

Van de Wall, R.H. “The Mission Field Zoutpansberg.” Comforter no. 1, 8 (1911): 3.

\section{Articles}

"Brother Fockler's Visits." Comforter no. 7, 6 (1927): 9.

“Brother J.O. Lehman's Letter.” Bridegroom's Messenger no. 5, 115 (1912): 1.

“Choosing to Die.” Rand Daily Mail 7 July 1909, p. 7-8.

"Conference of Native Ministers." Comforter N.S. no. 2, 2 (1932): 11.

"From the Mission Fields: Potgietersrust." N.S. no. 1, 4 (1932): 12.

"From the Mission Fields: Potgietersrust.” N.S. no. 1, 5 (1932): 18.

“God Has Visited Africa." Apostolic Faith no. 11 (1909): 1.

"Ministers in the Native Work." De Trooster (Mar 1919): 3.

"Missionary News: Potgietersrust." Comforter N.S. no. 2, 4 (1933): 8.

"Missionary News: Potgietersrust." Comforter N.S. no. 2, 12 (1933): 8-9.

"Native Work," Comforter no. 1, 8 (1911): n.p.

"Pentecost Among Africans." Apostolic Faith no. 14 (1910): 3-4.

"Potgietersrust." Comforter no. 11, 2 (1931): 6.

"Potgietersrust." Comforter N.S. no. 1, 8 (1932): 22.

“The Mission Field." Comforter no. 4, 4, (1924): 4.

“The Mission Field: Potgietersrust." Comforter no. 10, 8 (1930): 5.

"The Mission Field: Waterberg." Comforter no. 10, 3 (1930): 7.

"The Raising of the Dead." Apostolic Faith no. 11 (1909): 1.

"Verslag van Bro. Letwaba." De Trooster (Mar 1919): 6.

"Waterberg." Comforter no. 9, 10 (1927): 8.

"What the Lord is Doing Among the Natives." Comforter no. 1, 9 (1912): 12.

"Work Among the Natives in the Zoutpansberg and Elsewhere." Weekly Evangel (June 1916): 12.

“Zion in South Africa." Leaves of Healing no. 35, 25 (1915): 392-3.

\section{Archival sources}

Apostolic Faith Mission Archives, Kempton Park (AFM). Minutes of the Apostolic Faith Mission Executive Committee, 1908-1914.

Apostolic Faith Mission Archives, Kempton Park (AFM). Minutes of the Apostolic Faith Mission Executive Committee, 1915-1920.

National Archives of South Africa, Pretoria (NASA) 
Morton Elias Letwaba, the Apostolic Faith Mission, and the Spread of Black Pentecostalism in SA

TAB SNA 186 NA 3007/03 Elias Malatsie Letwaba, Bapedi Lutheran Church

TAB SNA 50 NA1743/02 Letter from Ministers and Teachers.

TAB SNA 141 NA 1429/03. Native Commissioner Eastern Transvaal asks for Ruling.

TAB SNA 401/771 S. Brander to Native Commissioner, 13 March.

TAB SNA 472 NA2441/10 Hook to Godley, 29 July.

SAB GNLB 205 File 22 The Apostolic Faith Assembly of South Africa.

SAB GNLB 205 File 34 Ethiopian Catholic Church in Zion.

SAB GNLB 205 File 61 Zion Apostolic Church.

SAB MHG 4053/59 Elias Mpahlele Letwaba.

\section{National archives of South Africa}

University of the Witwatersrand, Cullen Library, Church of the Province of South Africa Historical Papers (CPSA) File A3181 Christian Beliefs in Sekhukhuniland, n.d. 